\title{
Research on Education Cooperation and Cultural Exchange Between Chinese and Russian Design Specialties in Heilongjiang River Basin*
}

\author{
Yuyun Wang \\ Heihe University \\ Heihe, China
}

\author{
Hui Ma \\ Heihe University \\ Heihe, China
}

\begin{abstract}
In order to give full play to the resources and geographical advantages of the Heihe University in the border, promote the sharing of high-quality resources, expand the space for international exchanges and cooperation and deepen the connotation of cooperation, this paper analyzes how SinoRussian cooperation in running joint schools can be conducted in the major of art design in Heihe University and sums up experiences so as to promote such cooperation more perfect.
\end{abstract}

Keywords—art design; cooperatively-run school; strategy

\section{INTRODUCTION}

Over the years, the art-designing major has always been following the path of connotative, characteristic and open development. In this process, the college has integrated and given play to its resources and the geographical advantages of the Sino-Russian border to improve the running level of schools comprehensively, with the curriculum construction as the core, the application-oriented talent training model as the entry point, the basic capacity building and the construction of Sino-Russian quality teachers as the guarantee, and the quality and characteristics as the aim. The construction of cooperatively run schools takes the initiative to serve the economic development and social progress; it is based on Heilongjiang, develop towards the whole country, and radiates its influence across Russia; and it keeps cultivating the application-oriented innovative artistic design talents with both professional excellence and moral integrity, deep thoughts and good Practice" for the development of regional cultural and creative industries. The measures are as follows:

\section{Vigorously PROMOTING THE CONSTRUCTION OF CURRICULUM GROUP AND CREATING JOINT CHINESE- RUSSIAN CLASSROOMS}

In accordance with the orientation of serving the local economic and cultural construction and developing towards

*This article is one of the research projects of Heilongjiang Provincial Department of Education research fee on Russian Far East think tank research - "Russian Far East area folk art image research" 18KYYWFZK02 results.

This article is one of the achievements of the Heilongjiang Province Art and Science Planning Project "Inheritance and Comparative Study of Russian Folk Crafts in Heilongjiang River Basin” (2017D084). the cultural and creative industries in the border area as well as the whole country, majors and major fields will be set and adjusted dynamically to optimize the major structure; the Penetration and interaction among different majors, major groups and the between Chinese and Russian college education will be strengthened, to bring the integration of the major platform of art design and the subdivision of the major direction to an organic state, realize the close connection between the specialty chain and the industrial chain, so that the sustainable development of major construction will remain; the cultivation of innovation spirit, entrepreneurship awareness and entrepreneurship ability should especially run through the entire professional teaching. By constructing four key specialties, four Sino-Russian specialty groups with relevant majors and major orientations will be formed.

- A specialty group of visual communication will be established with the advertising media art major as the leader, radiating the specialty group of graphic design and display design etc.

- A specialty group of environmental art will be established with the major of interior design and engineering management as the leader, radiating the majors of interior design, environmental art design, landscape design, sculpture design, etc.

- A specialty group of decorative arts will be established, with the major of decorative arts design as the leader, to promote ceramic art, decorative painting and other majors.

- A specialty group of digital art will be established, with film and television animation as the leader, to promote digital media technology, entertainment software technology and other majors.

\section{UPDATING THE EDUCATING AND TEACHING CONCEPT AND REFORMING THE MODE OF TRAINING TALENTS}

The reform of the innovation and entrepreneurship talent training model that combines working with learning with studio system as the core should be deepened continuously, adhering to the combination of work with learning and teaching through practice. Cooperation with Russian and domestic industry enterprises in talent training should be 
strengthened, with the training studio in and out the school and in Russia. Each party should conduct the joint development of curriculum, joint implementation of teaching, joint investment in equipment, joint development of projects. With joint efforts of schools, enterprises along with the governments, the interaction between China and Russia, the connection between major setup and industry profession, between talent training specifications and industry requirements, between schoolwork and social occupation should be truly realized. The sense of social responsibility, spirit of innovation, sense of entrepreneurship and the ability of self-employment of students should also be promoted.

\section{A. Reform of Major Curriculum System}

The college should establish a modular and integrated professional curriculum system that features vocational competence training and is in accord with the requirements of occupation (groups). It should implement a task-driven and team-working studio teaching modal of the project taskdriven, team-based studio teaching model. That means:

- Tradition and modernity, art and technology, inheritance and innovation should be fully integrated in the studio teaching so that the simultaneous training of students' professional ability, occupational ability and professional quality can be conducted.

- Theory teaching and practice teaching should be integrated and the process of teaching, practice and production should be integrated, so that the simultaneous training of productive practical ability and creative ability of students can be conducted.

- The integration and professionalization of the curriculum should be strengthened in the practical studio teaching; through the introduction of the projects theme teaching and the connection between the modules of the curriculum system and the function of the studio, should be implemented, so that the simultaneous training of students' theoretical and practical ability, creative and creativity realizing ability, designing and producing ability, occupational innovation and innovating ability can be conducted.

\section{B. Construction of Special Chinese and Russian Courses}

With reference to the education concept of art design in Russian universities, the college should develop the curriculum standards and revise the teaching plan and syllabus jointly with the enterprise industry; it should attach importance both to the combination of the regular maintenance and dynamic revision of the teaching plan and the syllabus; and it needs to form methods and means that integrate national professional standards and curriculum teaching.

The school should, in cooperation with the enterprise industry in the Far East of Russia, build a number of excellent courses that reflect the latest technological achievements and real production processes or business processes, and develop a number of experimental and practical courses for the training mode of Sino-Russian cooperation practice innovation and entrepreneurship.

\section{Construction of a Shared Resource Library of Art Design Education}

In accordance with the principles of openness, sharing, scalability and high reliability, the college should integrate and develop high-quality teaching resources in various fields of art design, as well as the design information and results in national, provincial and municipal art galleries, libraries, and Sino-Russian art design training centers. At the same time it should introduce and develop resources in related fields at home and abroad, and build a comprehensive resource library of shared art design education with industry enterprises and independent intellectual property rights, to build a public service platform for the transmission and application of the teaching in art design and arts and crafts design and of Chinese design culture and Russian traditional craft culture.

\section{ESTABLISHING A TEACHING, ENTREPRENEURSHIP TraINING AND PRACTICE BASE FOR CHINESE AND RUSSIAN COLLEGE STUDENTS}

The college should integrate the talents, technology, information, facilities, equipment, capital, and other resources of Chinese, Russian schools, enterprises, and industries based on the principle of "cooperation, cooperation, and mutual benefit," to build an on-campus training center for Chinese and Russian schools(studio groups), an off-campus training base and a training center Russian art design. So that a modern, professional, open, productive and creative internship training environment can be built to provide support for the "studio-system" innovational and enterprising talents training model and talent development program that combines work with learning.

\section{A. On-campus Training Center (Studio Group)}

The college should cooperate with enterprises to build the model and mechanism of the on-campus training studio; it should focus on building four studio groups corresponding to the four key professional core courses, and build three more training bases at the provincial level and above on the basis of the "Russian training base in Blagoveshchensk" and the "Heilongjiang Provincial University Art Design Experimental Teaching Demonstration Center.

\section{B. Sino-Russian Off-campus Practice Base}

The college should focus on building an off-campus training base that connects specialty and industry, and emphasize deep cooperation with well-known enterprises in the industry, creative industrial parks in the region, and Russian traditional arts and crafts industry associations. It should establish a cooperative form of off-campus course training, post-practice, vocational apprenticeship, etc. with studio as the carrier, and conduct deep cooperation in professional development, curriculum development, practical teaching mode development, design project development, 
textbook course compilation and teacher training, etc. with the above organizations. A school-enterprise, Sino-Russian cooperation training base should be established, to fully meet the needs of art design students for internships of more than half a year.

\section{Exploring the Establishment of a Long-term Mechanism for the Operation of Training Bases Inside and Outside School}

The college should strengthen the connotation construction of training bases inside and outside the school, and jointly explore with the cooperative enterprises to establish a long-term management system for off-campus training bases (methods for students' off-campus internship management), taking "innovation, openness, and service" as the principle and starting point of system construction, to promote the sharing of resource of good quality among majors, schools, and between China and Russia thus improve the utilization benefit and service levels of resources.

\section{BuILDING A High-LEVEL SINO-RUSSIAN COOPERATION FACULTY AND PRACTICE TEAM}

The college should form an effective "double-type" teacher team introduction, training, management mechanism, focusing on specialty leaders, backbone teachers and enterprise technology backbone part-time teachers, through selecting teachers with strong innovation and entrepreneurship in the school and off-campus, Russian talent training experts, the enterprise management personnel as mentors, to build a high-level teacher team with "double quality" and "double structure".

\section{A. Establishing a Part-time Teacher Resource Pool to Improve the "Double Division" Structure}

To establish a part-time teacher resource pool is to achieve the sharing of high-quality teachers in the society. The resource library implements dynamic replacement and continues to exhale the old and inhale the new. Relying on China's various art design universities, research institutes and Russia's rich environmental and cultural resources, the college should invite academic experts, industry masters and management experts from universities at home and abroad to provide short-term lectures, training guidance, new technology introduction, project research and engineering. And it should introduce high-quality human resources in the enterprise industry, and enrich the optimization of the teaching staff through school-enterprise joint development projects and various types of studios built with joint efforts.

\section{B. Establishing "Two Echelons" to Train and Introduce \\ Chinese and Russian "Double-Skilled" Quality Teachers}

The college should focus on the construction of professional leader echelon and youth backbone teacher echelon, to improve the overall level of the teaching team.

According to the needs of the college's key specialties in art design and specialty group construction, 10 professional leaders will be introduced and trained during the three-year construction period, 30 key teachers will be introduced and trained, and 10 "senior double teachers" (professor + senior craft artist) will be trained; teachers will be selected in batches to go out of college to enter the enterprises or even go abroad to go to domestic and foreign first-class colleges, teacher training bases, enterprise training and further studies, to learn advanced art design education teaching concepts, advanced technology and management methods. In the threeyear plan, 20 teachers are to be selected to study in domestic universities, 10 teachers go to the Russian art design studio to study, and 30 teachers enter the enterprise for field practice.

\section{MAKING GOOD USE OF THE EXPERIMENTAL}

INDUSTRY PLATFORM AND BASE CONSTRUCTION, STRENGTHENING CHARACTERISTICS AND ADVANTAGES, AND STRENGTHENING EXCHANGES WITH RUSSIA

Relying on the inter-university cooperation with Russian universities, the college should expand the cooperative partners of design majors, strive to improve the level of cooperation and carry out substantive cooperation. Since the existing Chelymhowa sketching base is more focused on painting and sketching, the design majors should take this opportunity to establish a base and information collecting spot for art design and communication. And it should establish a cooperation platform to exchange students with Russian universities or set up workshops for groups consisted by Chinese and Russian students aiming at solving a certain subject. In the end of each study period they can disseminate their results in the form of report of achievement.

With a unique geographical advantage in the exchanges with Russia, Heihe University should embody this advantage in the cultivation of talents through introducing teaching concepts, curriculum systems and high-quality teaching materials. In communication, not only should Russian characteristics be absorbed, Chinese historical and cultural features should also be highlighted. Such as Russian architecture, color matching, packaging design, book design, patterns, etc. all can be the materials and inspiration of design. Blending Chinese and Western cultures, constructing practical courses of Chinese and Russian characteristics and inheriting and developing Chinese traditional culture from the perspective of design, can both keep national characteristics and remain modernity.

\section{Hosting High-LeVEl ACtivities, CONDUCTING ACADEMIC EXCHANGES, AND CREATING AN ARTISTIC BRAND IMAGE}

By inviting famous and famous schools and famous teachers to go to the base to collect the wind, the college can spread Chinese culture and art while building bridges for cooperation and exchanges between domestic institutions and Russia. The college should organize high-level international academic exchange activities, to continuously consolidate and expand the exchanges and cooperation between education, culture and art of this college and Russian universities. Through providing sketching and creating site for other domestic art schools and domestic painters, the college can build a new platform of Sino- 
Russian art and education exchanges. On this platform can the culture of China and Russia interact and collide, making the design specialty the bond for cultural exchange between domestic and Russian universities, thus promoting the sound development of frontier art. Under the framework of the China-Russia "State Years" and "Language Years", it hosted one of the activities of the "Educational Friendly Weeks" organized by the Provincial Department of Education in Amur Prefecture, which is "Exhibition of Excellent Works from Chinese and Russian University Teachers and Students"; it organized the "Art Creation Summit Forum of the Five Schools in Heilongjiang Province and the Five Schools' Teacher and Student Works Exhibition", and three high-level activities such as the Russian Oil Painting Master Class of the Ministry of Education, all of which received widespread attention from the domestic and international art circles. Over the years, this college has hosted the "Exhibition of Amur State University Process Design Department Teacher and Student Works", the Russian "Chinese Year", " 'Chinese Style' Chinese Painting Masters Exhibition", and the "National Day Celebrating"" SinoRussian Teacher Works Exhibition". The holding of various large-scale events is a comprehensive display of the experimental teaching level and scientific research achievements of the design department, and it is also a comprehensive review of the strength of the design professional practice.

\section{CONCLUSION}

Through reform, the talent training mode and the new practice teaching system of the design specialty are combined with each other. The development of the design specialties relies on the existing national specialties of the College of Fine Art and Design, national comprehensive reform pilot project, the provincial key specialties, and the provincial art experiment demonstration center. It will, in terms of Sino-Russian resource integration, personnel training, teaching and research, experimental team building and serving the society, form the following features: The first is to introduce Russian design education resources and strengthen cooperation and exchanges with Russian universities and art groups; to hire Russian foreign teachers to work in the design profession, and organize various academic exchange activities between China and Russia, such as lectures, art exhibitions, and joint laboratories, and send students to the experimental studios of their respective institutions for short-term study. The second is to build a characteristic practice course. The design department adopts the experimental teaching methods and means that combines design-based experimental courses with domestic and international art competitions and makes domestic exchanges and international exchanges benefit each other. It strengthens artistic edification and training from inside and outside the classroom, and closely combines theory and experiment in curriculum design to cultivate students' comprehensive quality. It is the embodiment of this kind of achievement that students become frequent winner in art competitions. At the same time, it draws on the Russian syllabus, constantly expands the teaching content, and offers courses in Russian ceramic art, batik, modern Russian painting, and Russian folk art, in order to stimulate students' enthusiasm for independent learning and improve the overall quality of students. The third is to create the Sino-Russian cooperative experimental teaching system. The design department focuses on the training objectives of high-level applied talents of the university, and gears to the regional economic construction. It adopts a multi-level and modular experimental teaching system, and attaches importance to the cultivation of students' practical ability in teaching practice. More attention is paid to the close integration with theoretical knowledge, so that students become senior talents with increasing innovation consciousness in the close combination of theory and practice. Through the introduction of foreign teachers, teaching materials and experimental models, the teacher structure was optimized, and the advanced teaching concepts and cutting-edge teaching contents of foreign countries were brought to the center, which laid the foundation for the improvement of practical teaching quality.

\section{REFERENCES}

[1] Yu Tongyuan. Research on the modern transformation of Chinese traditional craftsmen [D]. Fudan University, 2005 (5). (in Chinese)

[2] Xiao Qunzhong, Liu Yongchun. The craftsman spirit and its contemporary value [J]. Social Sciences in Hunan , 2015 (11). (in Chinese)

[3] Zha Guoshuo. The modern value implication of craftsman spirit [J]. Vocational \& Technical Education Forum, 2016 (3). (in Chinese)

[4] Du Guangping. Connotation analysis and system analysis of modern apprenticeship system in China[J].Chinese Vocational and Technical Education, 2014(30).(in Chinese)

[5] Zhang Wen. Research on the cultivation mode of college art talents based on the traditional "artisan spirit"[J]. Design Research, 2015(3). (in Chinese)

[6] Dong Gang. Integrating professionalism into the whole process of talent cultivation [N]. China Education Press Agency, 2015.12.22. (in Chinese)

[7] Zhu Jinhui. Belt and Road: the dreaming space of Chinese craftsman spirit [J]. ZHUANGSHI, 2017. (1): 74-75. (in Chinese) 